\title{
Integrated techno-economic assessment of a biorefinery process: The high-end valorization of the lignocellulosic fraction in wood streams
}

\author{
Maxim Tschulkow ${ }^{\mathrm{a},{ }^{*}}$, Tine Compernolle ${ }^{\mathrm{b}}$, Sander Van den Bosch ${ }^{\mathrm{c}}$, Joost Van Aelst ${ }^{\mathrm{c}}$, \\ Ilié Storms ${ }^{d}$, Miet Van Dael ${ }^{e}$, Gil Van den Bossche ${ }^{c}$, Bert Sels ${ }^{c}$, Steven Van Passel ${ }^{a}$ \\ a Department of Engineering Management, University of Antwerp, Prinsstraat 13, 2000, Antwerp, Belgium \\ b Department of Economics, University of Antwerp, Prinsstraat 13, 2000, Antwerp, Belgium \\ ' Center for Sustainable Catalysis and Engineering, KU Leuven, Celestijnenlaan 200F, 3001, Heverlee, Belgium \\ d Department of Earth and Environmental Sciences, KU Leuven, Celestijnenlaan 200E, 3001, Heverlee, Belgium \\ e Unit Separation and Conversion Technologies, VITO, Boeretang 200, 2400, Mol, Belgium
}

\section{A R T I C L E I N F O}

Keywords:

Biomass conversion technology

Biorefinery

Lignocellulose

Reductive catalytic fractionation

Techno-economic assessment

Wood valorization

\begin{abstract}
A B S T R A C T
A new lignin-first biorefinery with a reductive catalytic fractionation process, which targets the valorization of the lignin and the carbohydrate fraction into higher value end-products, is currently being designed. To identify the various $R \& D$ drivers for projects with a low technology readiness level (TRL), we developed an integrated techno-economic assessment (TEA) that directly integrates the results of lab studies with economic costs and benefits. Furthermore, different linkages are made to upstream wood availability and downstream demand to understand its fit into existing wood value chains. By making the relations across the wood value chain explicit within the integrated TEA, we find that the scale of the plant, the feedstock-specific output quantities, and output prices highly determine the economic feasibility. Furthermore, this detailed analysis reveals the importance of assessing different types of feedstock. If only virgin wood is available as feedstock, minimum capacity levels between 190 and 234 kilotons per year are needed for the investment to be profitable. Waste wood proves to be the most profitable feedstock with an NPV of M€ 59 and an IRR of $26 \%$. Using only waste wood as feedstock makes the investment profitable at a lower capacity level of 80 kilotons per year and economic shocks can be absorbed. Based on these results we show that an integrated and detailed TEA is indispensable to define future development paths for early-stage, innovative technologies.
\end{abstract}

\section{Introduction}

Due to the population growth rate and the associated increasing consumption, our world is transgressing its planetary boundaries (Rockström et al., 2009). Current fossil-based production processes are causing several environmental, social, and economic problems. To mitigate these destructive processes, our society must undergo substantial changes and find alternative, more sustainable production systems. The transition towards a bio-economy is part of

\footnotetext{
* Corresponding author.

E-mail addresses: maxim.tschulkow@uantwerpen.be (M. Tschulkow), tine compernolle@uantwerpen.be (T. Compernolle),sander.vandenbosch@kuleuven.be (S. Van den Bosch), joost.vanaelst@kuleuven.be (J. Van Aelst), ilie.storms@ kuleuven.be (I. Storms), miet.vandael@vito.be (M. Van Dael), gil.vandenbossche@ kuleuven.be (G. Van den Bossche), bert.sels@kuleuven.be (B. Sels), steven. vanpassel@uantwerpen.be (S. Van Passel).
}

these required changes and biorefineries can form the fundaments upon which to build this bio-economy. To achieve this transition, the potential to produce bio-based energy, chemicals, and materials must be realized (Kamm et al., 2010), which means that new technologies need to be developed. The conversion of wood streams into high-value products holds the potential to support and accelerate the transition towards a sustainable bio-economy.

The industrial refining of wood started at the beginning of the 19th century with large-scale paper production and the emergence of related industries such as cardboard and pulp. Wood was also used for saccharification purposes (Kamm et al., 2010). The waste product resulting from this conversion process mainly consists of a black liquor that contains aqueous streams of lignin-derived products, hemicellulose, and alkaline chemicals. Mostly, this lignin comprising waste fraction is used for the production of energy. Hence, the current production processes do not valorize the woody biomass to its full extent (Calvo-Flores and Dobado, 2010). 
However, a new lignin-first biorefinery process, reductive catalytic fractionation (RCF), is being designed, which specifically targets the conversion of lignin into a valuable lignin oil that can be used to produce higher-value end-products such as lignin-derived (mono and oligo) phenolics (Renders et al., 2019). This process combines solvolytic action and catalysis to produce a depolymerized and stabilized lignin oil, with high chemical functionality, next to a solid (hemi) cellulose pulp (Renders et al., 2017). A comparison between several biorefinery technologies made by Schutyser et al. (2018) showed that RCF-technology has the most promising phenolic monomer yields, while the oligomer fraction is highly functionalized.

Even though the RCF-technology improves the current technological status, its implementation will not be successful if certain market conditions are not fulfilled. Therefore, the wood value chain needs to be assessed ensuring the availability of the feedstocks and the market for the targeted end-products. Verkerk et al. (2019) showed that Western Europe has a high unused wood biomass potential. However, it is not equally distributed within Western Europe. Certain areas have sub-optimal conditions for the location of a wood-based biorefinery. The minimal profitable capacity level of the biorefinery depends on the local feedstock supply, infrastructure, and market conditions. Looking at the downstream demand, these products have the potential to target a variety of consumer markets.

Despite the technological advancement of this innovative RCFprocess, the key elements that determine its economic feasibility have never been defined in detail. Therefore, the first objective of this paper is to present the first fully-integrated techno-economic assessment of such RCF-process within the wood value chain.

Several techno-economic assessment (TEA) studies have been performed on wood-based biorefinery processes to determine the economic feasibility of single-feedstock wood, such as poplar (Cheali et al., 2016), red maple (Bond et al., 2014), and beech wood (Budzinski and Nitzsche, 2016). However, these TEA studies mainly limit their scope to the production of low-valued products and they do not analyze the potential of further valorization of wood. Another gap in traditional TEA's is the rigid structure and lack of focus on the multi-dimension aspects of the value chain. To face the long-run trend towards greater biodiversity in forests (Messier et al., 2019) and feedstock supply uncertainties, underlines the need for flexible biorefineries considering several feedstocks rather than a single one. Failure to take these contingencies into account holds a risk of misleading results followed by sub-optimal investment decisions. Therefore, the second objective of this paper is to introduce an integrated TEA that can be adjusted to changing research and development (R\&D) outcomes and to changes at different value chain stages - upstream feedstock's availability and supply-side boundaries, midstream process-based technical and economic parameters, and downstream price and demand processes for the end-products - simultaneously. The adaptability of the TEA is highly relevant to assess R\&D projects that are characterized by technical and market uncertainty. Taking a variety of different technical and economic parameters into account, this analysis can accelerate technological improvements as it reveals the crucial factors for early investments and the allocation of financial resources for the subsequent $R \& D$ steps.

\section{Method}

A TEA is often carried out on new technologies to improve the environmental and social impacts by its design and helps decisionmakers make strategic investment decisions (Kuppens et al., 2015). The traditional TEA consists of four steps: (a) Market study, identifying market-related parameters potentially influencing the commercialization ability of the project; (b) a process flow diagram (PFD) and a mass and energy balance (MEB) providing a schematic overview of the main process units, inputs, and outputs of the process; (c) an economic assessment analyzing the economic feasibility based on technical and economic variables; and (d) a sensitivity analysis showing the most influential and/or critical variables affecting the economic performance of the biorefinery (Thomassen et al., 2019).

\subsection{Integrated techno-economic assessment}

The integrated TEA makes linkages between different variables of the technical and economic units. A change in one input variable directly affects multiple-linked intermediate variables, which in turn determine the different output variables, as shown in Fig. 1. Input and intermediate variables are extended by newly introduced sub-variables which existing TEAs are lacking. A sub-variable makes it possible to modify certain variables on a deeper technical and economic level and enables the decision-makers to understand the variable-specific processes that affect the operating process of the technology. For instance, assessing the wood value chain, moisture content as a sub-variable affects drying and transportation cost on the supply-side and end-product output yields on the RCF-process side. This opens up a new possibility of a more in-depth techno-economic impacts assessment.

Most of the existing TEA papers evaluate commercialized technologies on a high technology readiness level (TRL) considering only one wood species. Bond et al. (2014), for instance, evaluate an nth-commercial plant on a high TRL limiting its study on red maple as a feedstock. Our integrated TEA, on the other hand, uses RCFbased laboratory studies on a low TRL. It is tested for different types of feedstock revealing differences in species-specific feedstock cost and end-product yield compositions.

All these modifications directly affect the PFD and the MEB, which in turn changes the economic-linked variables in capital expenditure (CAPEX), operational expenditure (OPEX), and revenues, resulting in the net present value (NPV) and internal rate of return (IRR). Next, a Monte-Carlo sensitivity analysis identifies the most influential variables and makes it possible to directly build a set of relevant research targets. Simultaneously, it allows decisionmakers to link to the market study and to intensify R\&D on the most influential variables. The integrated TEA is designed in a modular way such that it can be integrated with other disciplinary models (e.g. environmental impact models). Furthermore, it ties perfectly into Cooper (1990) Stage-Gate process, which assesses every stage of an $R \& D$ project. The dynamic multi-variable dimension of the integrated TEA foresees adjusting the variables based on the stage-specific conditions of the project without rebuilding the model. This makes the integrated TEA indispensable for R\&D projects.

\subsection{Model assumptions}

We developed an Excel-based model that incorporates all four stages of the integrated TEA. Information that is gathered during the market study is passed to the PFD and MEB, which is interlinked with the economic assessment and the sensitivity analysis.

\subsubsection{Process flow diagram and mass \& energy balance}

The presented RCF-biorefinery is designed for the conversion of wood chips to carbohydrate pulp, lignin-derived monomers, and oligomers. The units used in this contribution is a scale-downed version using a reference process from a recent technical study, using an annual capacity of 2590 metric kilotons dry birch input per year (kt/y). Because this reference process includes further down- 

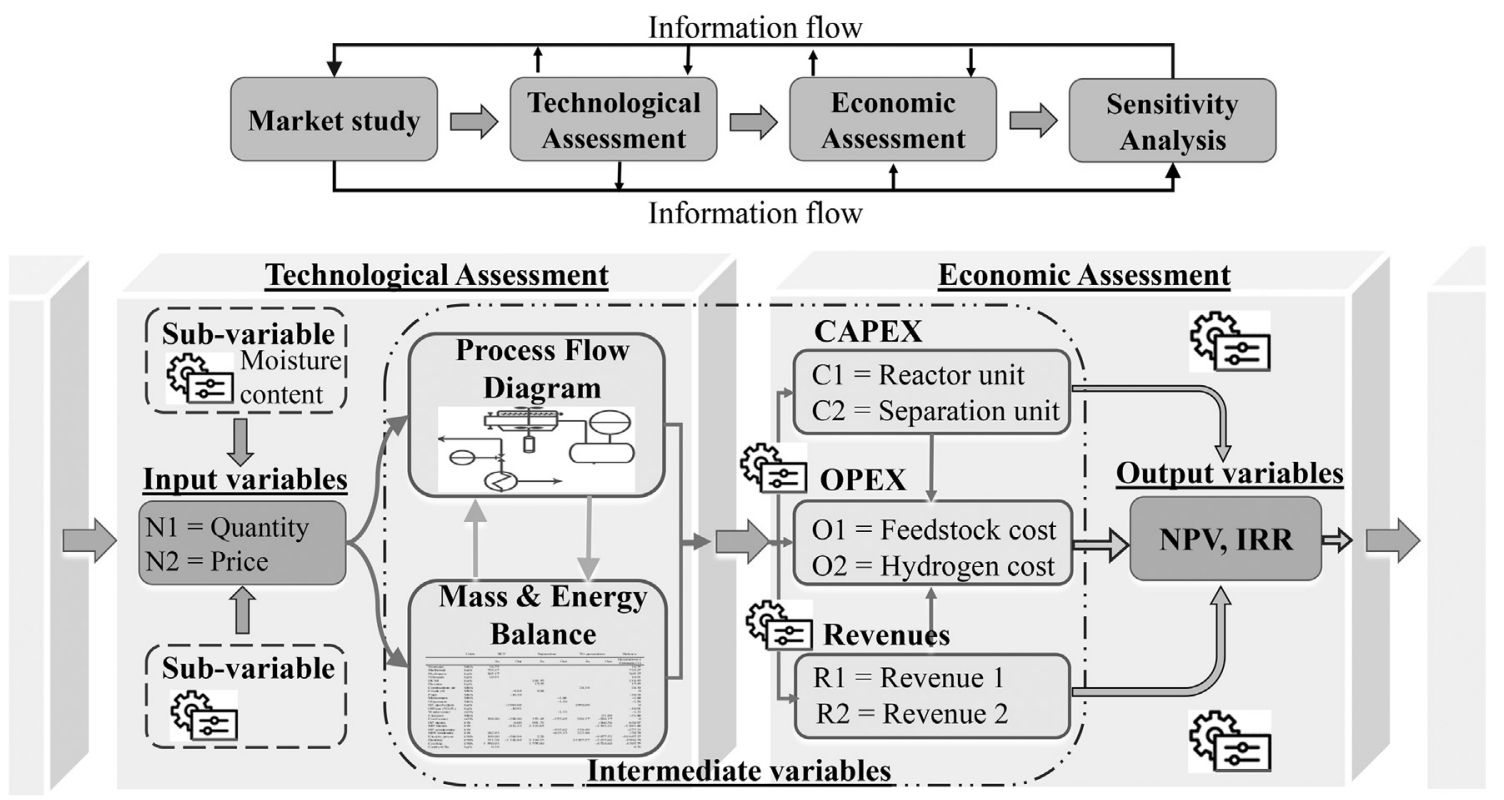

Fig. 1. Integrated techno-economic assessment.

stream processing of lignin-monomers to phenol and propylene, submodules (hydro-processing and de-alkylation \& distillation) are removed. Also, due to the smaller capacity modeled in this manuscript, the tri-generation unit, which produces energy by incinerating off-gas streams, is not realistic and therefore excluded. The main focus of this paper is the capacity level of $150 \mathrm{kt} / \mathrm{y}$ which is displayed in the PFD in Fig. 2. A detailed MEB for the processing of birch wood with a moisture content of $5 \%$ is shown in Table 1 (Liao et al., 2020).

The first subunit is the RCF-reactor system. This reactor is continuously fed with 18.75 dry metric tons per hour $(\mathrm{t} / \mathrm{h})$ wood chips from which lignin is fractionated by extraction and catalytic depolymerization and chemically stabilized in presence of methanol, hydrogen gas and a solid catalyst (here: ruthenium on carbon, $\mathrm{Ru} / \mathrm{C}$ ). The retention time in this subunit is $1.5 \mathrm{~h}$. After the reaction, filtration of the solid carbohydrate pulp results in $11.6 \mathrm{t} / \mathrm{h}$ pulp. Next, the solvent (methanol) is removed via distillation and introduced back into the reactor leaving a liquid oily product mixture, consisting mostly of phenolic monomers and oligomers from lignin, next to some solubilized carbohydrates. In a partial condenser, most of the hydrogen is recuperated together with methyl acetate (from hemicellulose) and a very small amount of methanol. Because of the presence of the methanol/methyl acetate azeotrope, further separation of them is economically unacceptable. Therefore, this so-called $\mathrm{H}_{2}$ gas bypass waste stream will be sent to an external-incinerator for heat recuperation. In the second subunit, the separation unit, crude lignin oil is washed with water to remove the carbohydrates, while the phenolic monomers and oligomers are extracted in dichloromethane. Purified lignin oil is obtained after the removal and recycling of dichloromethane. The aqueous sugar solution will be treated as wastewater. Finally, the purified lignin oil is treated by $n$-hexane to extract the light lignin monomers from the heavy lignin oligomers fraction leaving purified phenolic oligomers with a quantity output of $1.15 \mathrm{t} / \mathrm{h}$. Removal and recuperation of $n$-hexane results in purified phenolic monomers with a quantity output of $1.89 \mathrm{t} / \mathrm{h}$, respectively.

\subsubsection{Net present value}

For a firm, the decision to invest in a new plant or new industrial processes depends on the profitability of such projects. In this paper, we used both, NPV and IRR, to assess the economic feasibility of the RCF-biorefinery process. Equation (1) describes the NPV, which calculates the discounted current value of the future cash flows resulting from the initial capital investment (CAPEX). If the NPV is larger than zero, the investment is considered profitable and worthwhile to be undertaken. If the NPV is smaller than zero, the firm should forego investment in the project. The IRR is the internal discount rate for which the NPV is zero. If the IRR is greater than the discount rate, the project is considered profitable (Eq. (2)).

$$
\begin{aligned}
& N P V=\sum_{t=1}^{n} \frac{C F_{t}}{(1+i)^{t}}-\text { CAPEX, } \\
& 0=\sum_{t=1}^{n} \frac{C F_{t}}{(1+I R R)^{t}}-\text { CAPEX }
\end{aligned}
$$

The net cash flow $\left(C F_{t}\right)$ in year $t$ is the difference between annual discounted revenues and operational expenditures (OPEX). The discount rate $i$ is 15\%. The CAPEX represents the initial capital investment in year 0 . For the RCF-biorefinery, we consider a project lifetime of 20 years $(n)$.

\subsubsection{CAPEX and OPEX}

In determining the CAPEX, one of the main challenges in projects at a low TRL is the availability of precise cost data for a particular capacity or equipment size. For the RCF-biorefinery the precise scaling factor is unknown. Therefore, we use the 'six-tenth' rule to scale-down the total equipment cost of the RCF and separation unit based on the total equipment cost of the reference plant with a capacity of $2590 \mathrm{kt} / \mathrm{y}$ (Liao et al., 2020). The cost proportion of each submodule (i.e. RCF and a separation unit) is displayed in Table 2. Also, a storage facility (i.e. woodshed) is implemented that allows for a backup of seven days in case of interrupted feedstock supply. It is assumed that the end-products will be directly forwarded to the demand-side assuming no additional cost for storage facilities after the production process. For the base case scenario, we consider three capacity levels of an annual 20,75, and $150 \mathrm{kt}$ dry wood intake to cover various supply conditions of Western Europe. 

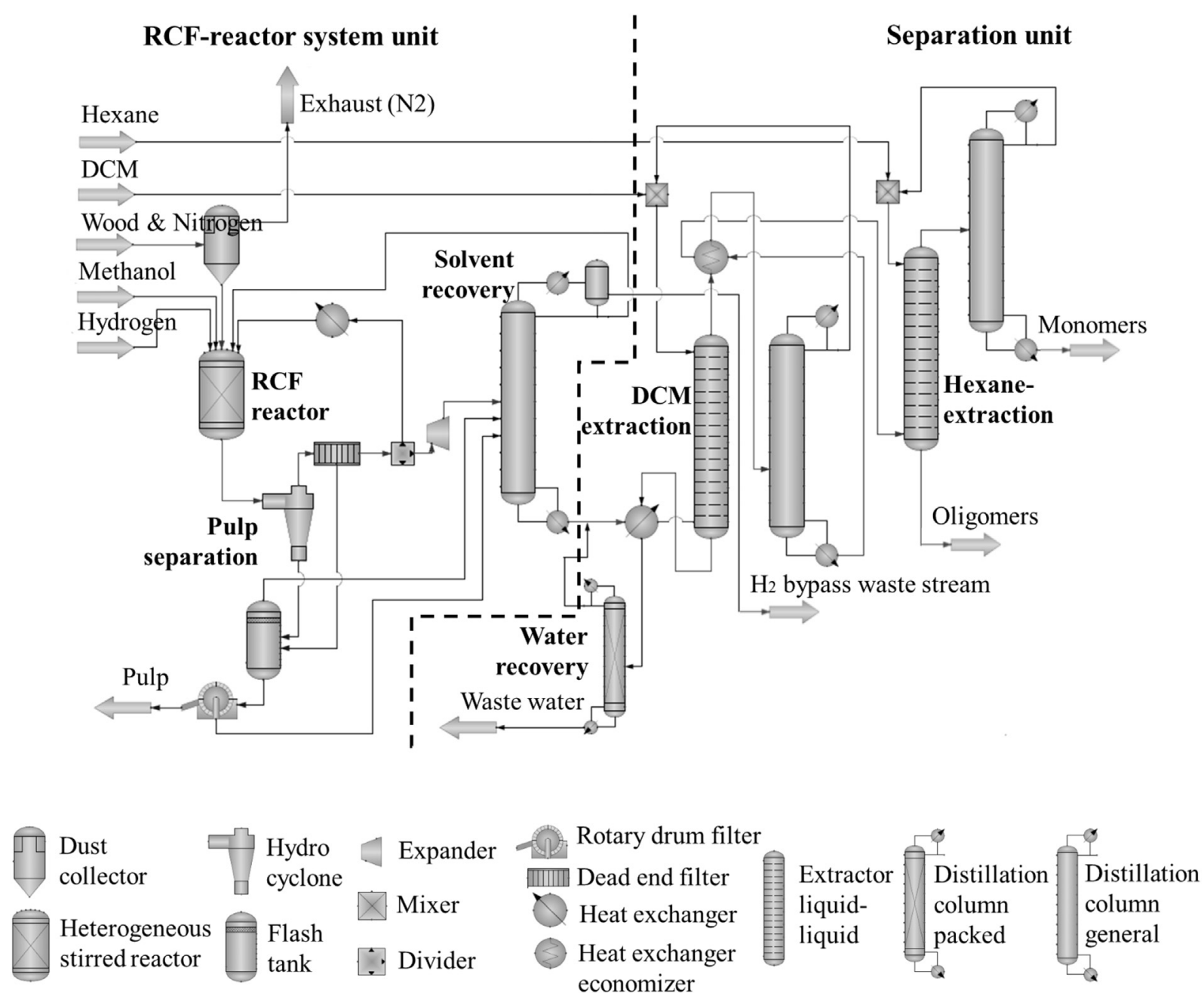

Fig. 2. Process flow diagram (Modification of (Liao et al., 2020)).

Following Peters et al. (2003), total delivered equipment cost (including 10\% delivery allowance) is multiplied by a factor of 5.03 to calculate the CAPEX.

The second major component of the economic assessment is the annual OPEX, which covers the costs of producing and selling the products listed in Table 3.

\subsubsection{Revenues}

Table 4 summarizes the three main revenue streams - pulp, monomers, and oligomers - for all three capacities. It is assumed that pulp is sold based on the sugar price. Note that the sugar price tends to be very volatile, it increased from $475 € / \mathrm{t}$ in 2010 , to almost $750 €$ in 2013, and then decreased to $320 € / \mathrm{t}$ in November of 2018 (European Commission, 2019). Thus, we estimated a longterm sugar price of $404 € /$ t. It is to emphasize that only $79 \%$ of the $11.6 \mathrm{t} / \mathrm{h}$ pulp output (Section 2.2.1) is considered sugar-based pulp, resulting in lower revenues. For both lignin-based endproducts, monomers and oligomers, prices of $1750 € / \mathrm{t}$ are assumed, reflecting the average phenol-formaldehyde resins market price within the range of $1500-2000 € / t$ (Van den Bosch et al., 2015).

\section{Results and discussion}

We first analyze the profitability of the RCF-process and the importance of scale. Then, we perform a Monte-Carlo sensitivity analysis. In the next step, various feedstock species and their combinations are assessed, followed by break-even point (BEP) analysis on capacity levels, feedstock costs, end-product prices, and discount rates.

\subsection{The importance of capacity level}

The scale is an important factor in the economic feasibility of the RCF-biorefinery. The NPV, corresponding to the three capacity levels with processing facilities of 20,75 , and $150 \mathrm{kt} / \mathrm{y}$ for birch, is outlined in Fig. 3.

Based on the current assumptions, a relatively small RCFbiorefinery with an annual capacity of $20 \mathrm{kt} / \mathrm{y}$ has an annual OPEX of $11.28 \mathrm{M} € / \mathrm{y}$ which is higher than the annual revenue of $9.68 \mathrm{M} € / \mathrm{y}$, resulting in an annual net cash flow of $-1.94 \mathrm{M} € / \mathrm{y}$. Hence, total cost increases from $\mathrm{M} €-25$ (CAPEX) to $\mathrm{M} €-35$ (NPV). Surprisingly, a larger-scale facility which processes $75 \mathrm{kt} / \mathrm{y}$ results in an even lower NPV $(\mathrm{M} €-42)$. Even though there is positive net cash flow of $2.3 \mathrm{M} € / \mathrm{y}$ for a scale of $75 \mathrm{kt} / \mathrm{y}$, the increase in total cumulated discounted net cash flow is lower than the increase in CAPEX. It shows that the benefits associated with economies of scale do not always outweigh the costs of the increase in scale and that there exists a minimum level of scale at which the NPV starts to increase. For $150 \mathrm{kt} / \mathrm{y}$ capacity, a positive cash flow of 
Table 1

Mass and energy balance for $150 \mathrm{kt} / \mathrm{y}$ birch wood (derived from (Liao et al., 2020)).

\begin{tabular}{|c|c|c|c|c|c|c|}
\hline \multirow[t]{2}{*}{ Category } & \multirow[t]{2}{*}{ Streams } & \multicolumn{2}{|l|}{$\mathrm{RCF}$} & \multicolumn{2}{|c|}{ Separation } & \multirow{2}{*}{$\begin{array}{l}\text { Balance } \\
\text { Generation }(+) \\
\text { Consumption }(-)\end{array}$} \\
\hline & & In & Out & In & Out & \\
\hline \multirow[t]{9}{*}{ Material input/output (kg/h) } & Feedstock & 18750 & & & & -18750 \\
\hline & Methanol & 1092.85 & & & & -1092.85 \\
\hline & Hydrogen & 181.32 & & & & -181.32 \\
\hline & Nitrogen & 11.25 & & & & -11.25 \\
\hline & $\mathrm{Ru} / \mathrm{C}$-catalyst & 0.165 & & & & -0.165 \\
\hline & Dichloromethane & & & 225.27 & & -225.27 \\
\hline & n-Hexane & & & 18.11 & & -18.11 \\
\hline & Water & & 0.332 & 0.471 & & -0.139 \\
\hline & Crude oil & & 5562.18 & 5562.18 & & 0 \\
\hline \multirow[t]{3}{*}{ End-products (kg/h) } & Pulp & & 11661.29 & & & 11661.29 \\
\hline & Monomers & & & & 1894.10 & 1894.10 \\
\hline & Oligomers & & & & 1149.61 & 1149.61 \\
\hline \multirow[t]{3}{*}{ By-products/waste streams (kg/h) } & $\mathrm{H}_{2}$ gas bypass & & 1582.22 & & & 1582.22 \\
\hline & Off gas & & 11.25 & & & 11.25 \\
\hline & Wastewater & & & & 3980.63 & 3980.63 \\
\hline \multirow[t]{8}{*}{ Energy-based streams (kWh) } & Cool water $\left(\mathrm{m}^{3} / \mathrm{h}\right)$ & 204.99 & 204.99 & 157.33 & 157.33 & 0 \\
\hline & HP steam & & & 1021.90 & & -1021.90 \\
\hline & MP steam & & 837.11 & 2188.70 & & -1351.59 \\
\hline & HP condensate & & & & 448.96 & 448.96 \\
\hline & MP condensate & 250.37 & & & 654.60 & 404.23 \\
\hline & Electric power & 112.34 & 289.54 & 2.35 & & 174.85 \\
\hline & Heating & 341.53 & 1177.85 & 2189.42 & & -1353.10 \\
\hline & Cooling & 1598.43 & & 1830.31 & & -3428.74 \\
\hline
\end{tabular}

Table 2

CAPEX for capacity levels of 20,75 , and $150 \mathrm{kt} / \mathrm{y}$ in $(\mathrm{M} €)$.

\begin{tabular}{lllll}
\hline Process unit & $\%$ & $20 \mathrm{kt} / \mathrm{y}$ & $75 \mathrm{kt} / \mathrm{y}$ & $150 \mathrm{kt} / \mathrm{y}$ \\
\hline RCF $^{\mathrm{a}}$ & & 4.13 & 9.12 & 13.83 \\
Separation $^{\mathrm{a}}$ & & 0.30 & 0.67 & 1.01 \\
Storage facility $^{\mathrm{b}}$ & & 0.04 & 0.17 & 0.34 \\
$\mathrm{H}_{2}$ gas bypass pipelines $^{\mathrm{c}}$ & & 0.11 & 0.27 & 0.44 \\
\hline Total equipment cost $^{\text {Delivered equipment cost }}$ & 100 & 5.05 & 11.25 & 17.62 \\
\hline CAPEX & $\mathbf{5 0 3}$ & $\mathbf{2 5 . 4 1}$ & $\mathbf{5 6 . 6 7}$ & $\mathbf{8 6 . 4 8}$ \\
\hline a Derived from (Liao et al., 2020). & & & \\
b (Kühmaier et al., 2016). & & & \\
c (Sinnott and Towler, 2019). & & &
\end{tabular}

Table 3

Annual OPEX for capacity levels of 20,75 , and $150 \mathrm{kt} / \mathrm{y}$ in $(\mathrm{M} € / \mathrm{y})$.

\begin{tabular}{lllll}
\hline Items & Cost in $€ / \mathrm{t}$ & $20 \mathrm{kt} / \mathrm{y}$ & $75 \mathrm{kt} / \mathrm{y}$ & $150 \mathrm{kt} / \mathrm{y}$ \\
\hline Material cost & & & & \\
$\quad$ Birch & 171 & 3.42 & 12.83 & 25.65 \\
Methanol $^{\mathrm{a}}$ & 393 & 0.46 & 1.72 & 3.43 \\
Hydrogen $^{\mathrm{b}}$ & 2100 & 0.41 & 1.52 & 3.04 \\
Nitrogen $^{\mathrm{a}}$ & 102 & 0.001 & 0.005 & 0.009 \\
Dichloromethane $^{\mathrm{a}}$ & 313 & 0.08 & 0.28 & 0.56 \\
Hexane $^{\mathrm{a}}$ & 712 & 0.01 & 0.05 & 0.10 \\
$\quad$ Ru$^{\text {CC-catalyst }}{ }^{\mathrm{a}}$ & 418000 & 0.07 & 0.28 & 0.55 \\
Operating cost $^{\mathrm{a}, \mathrm{c}, \mathrm{d}}$ & & $\mathbf{5 . 2 2}$ & $\mathbf{1 0 . 5 1}$ & $\mathbf{1 7 . 5 1}$ \\
General expenses $^{\mathrm{d}}$ & & $\mathbf{1 . 1 3}$ & $\mathbf{5 . 0 9}$ & $\mathbf{7 . 8 7}$ \\
R\&D $^{\mathrm{d}}$ & $5 \%$ of revenues & 0.48 & 1.82 & 3.63 \\
\hline Annual OPEX & $\mathbf{1 1 . 2 8}$ & $\mathbf{3 4 . 0 0}$ & $\mathbf{6 2 . 3 5}$ \\
\hline a (Liao et al., 2020). & & & \\
b (Thomas et al., 2016). & & & \\
c (Bridgwater et al., 2002). & & & \\
d (Peters et al., 2003). & &
\end{tabular}

Table 4

Annual revenues for capacity levels of 20,75 , and $150 \mathrm{kt} / \mathrm{y}$ in $(\mathrm{M} € / \mathrm{y})$.

\begin{tabular}{lllll}
\hline End-products & $€ / \mathrm{t}$ & $20 \mathrm{kt} / \mathrm{y}$ & $75 \mathrm{kt} / \mathrm{y}$ & $150 \mathrm{kt} / \mathrm{y}$ \\
\hline Pulp $^{\mathrm{a}}$ & 404 & 3.96 & 14.84 & 29.68 \\
Monomers $^{\mathrm{b}}$ & 1750 & 2.14 & 8.04 & 16.08 \\
Oligomers $^{\mathrm{b}}$ & 1750 & 3.53 & 13.25 & 26.50 \\
\hline Annual revenues $^{\text {Ang }}$ & & $\mathbf{9 . 6 8}$ & $\mathbf{3 6 . 3 1}$ & $\mathbf{7 2 . 6 1}$
\end{tabular}

a (European Commission, 2019).

b (Renders et al., 2018).

10.25 $\mathrm{M} € / \mathrm{y}$ leads to an increased NPV of $\mathrm{M} €-23.45$.

\subsection{Monte-Carlo sensitivity analysis}

To some degree, all variables incorporate uncertainties and variable values can change over time. Therefore, we performed the Monte-Carlo sensitivity analysis on an RCF-biorefinery with a capacity of $150 \mathrm{kt} / \mathrm{y}$ to indicate the variables with the highest impact on economics. In this case, 10000 iterations per scenario are simulated. Each iteration selects a random value between a minimum and maximum for all project variables, under the selected distribution shape. All variables are following a triangular distribution pattern characterized by a most likely value with a variance of $\pm 10 \%$. The tornado diagram in Fig. 4 illustrates ten sensitive variables that affect the NPV the most. The input bars to the left (right) represent a negative (positive) input correlation with the NPV.

The capacity exponent has the largest impact on the NPV representing the economies of scale (e.g. new technologies, productivity improvement, learning effects, etc.). The research focus should, therefore, be on improving and optimizing the plant facilities and its operations. Besides, capacity exponent directly affects the CAPEX of the capacity level which is ranked as the 8th most sensitive variable. At first appearance, the capacity level seems to 


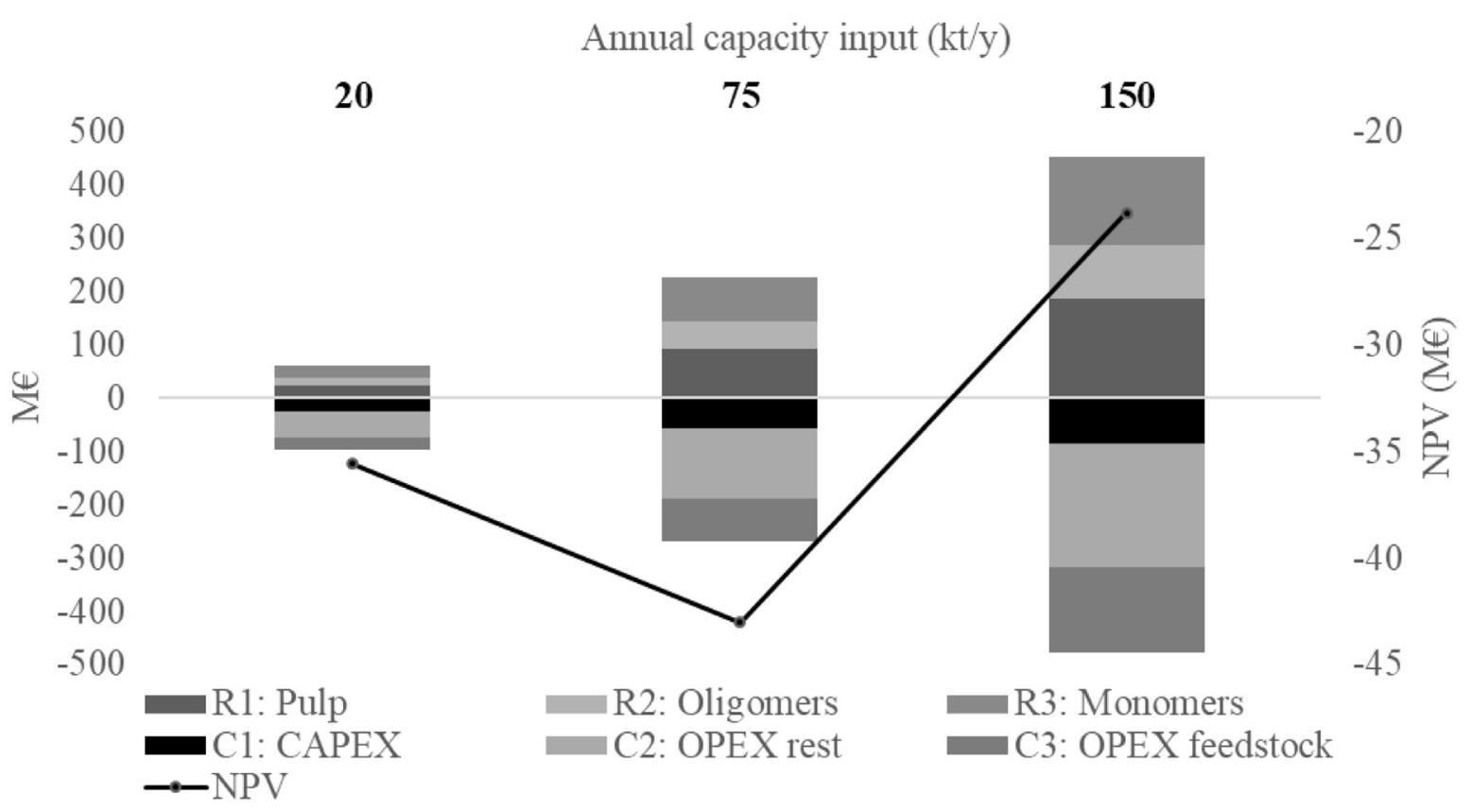

Fig. 3. Cumulative discounted revenues ( $R$, above), costs ( $C$, below), and NPV for the base case capacity levels.

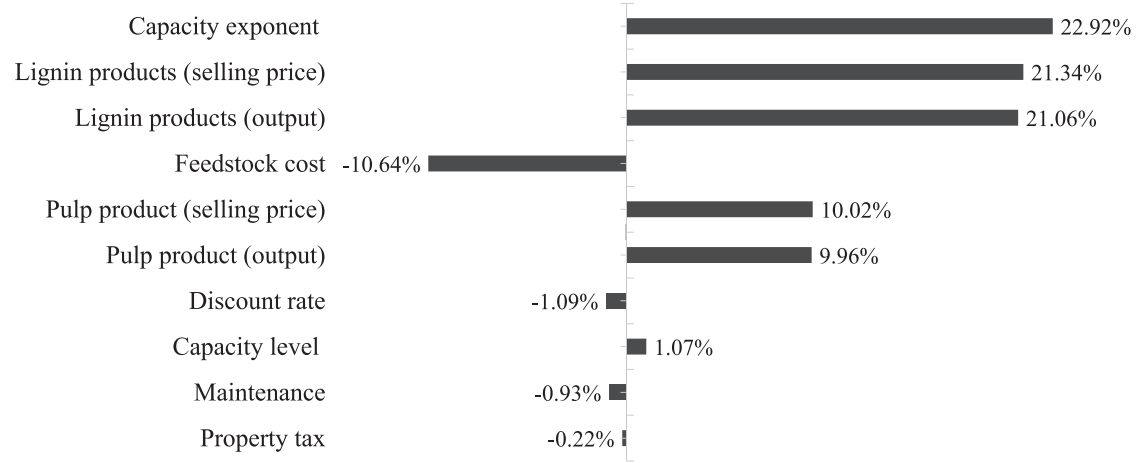

Fig. 4. Tornado diagram: Most sensitive variables and their contributions to variance in NPV.

be a variable with a relatively low impact. Note that capacity level change will not be limited to $10 \%$. In Section 3.1., starting from a capacity level of $20 \mathrm{kt} / \mathrm{y}$, a capacity increase of $375 \%$ and $750 \%$ was shown. Hence, the combination of both, capacity level and the capacity exponent, underlines the importance of scale and its effect on the profitability. Prices for pulp and lignin-based end-products are ranked as the 2 nd and 5th most influential variables, respectively. Potential advice is to focus on R\&D activities, aiming to improve the quality of the end-products with higher selling price potential. Looking at the demand-side, favorable advantages of the end-product must be communicated in an effective way to raise awareness and increase demand. Similarly sensitive are output yields of the end-products which have the 3rd and 6th largest impacts on the NPV, respectively. Potential further research can focus on feedstocks with higher output yield on the supply-side level or increased R\&D effort for further improvement of the RCFprocess. The feedstock cost (supply-side) is ranked as the 4th most influential variable. Lower processed feedstocks with lower prices are the potential targets. When it comes to the discount rate (7th), the focus should be on resolving the project-related uncertainties. This is a long-term process that needs $R \& D$ investments to be resolved.

Looking for potential economic improvement, Monte-Carlo sensitivity analysis revealed the most influential input variables which will be the fundament for the next assessments in Section 3.3 and 3.4.

\subsection{Different feedstock species and their combinations in dry wood condition}

Feedstock output yields (pulp, monomers, and oligomers) are very sensitive variables that can be improved by increasing $R \& D$ in process efficiency in the long-run. In the short-run, research on alternative species with potentially higher output yields should be aimed to boost the output yields. Therefore, an additional assessment is performed that studies the impact of different wood species and its output yields on the economic feasibility of the RCFbiorefinery.

Birch, poplar, pine, waste wood (type B), and their combinations are considered. Both birch and poplar are hardwood species. 
Approximately half of the European forest area is populated usually by coniferous species (Michel et al., 2018). As a representative of coniferous species, pine is also considered. Waste wood with its promising output yields is examined as the only non-virgin wood feedstock. The capacity level of $150 \mathrm{kt} / \mathrm{y}$ remains the same. The methanol consumption and $\mathrm{H}_{2}$ gas bypass generation changed to $531.94 \mathrm{~kg} / \mathrm{h}$ and $285.27 \mathrm{~kg} / \mathrm{h}$, respectively. Other species-specific changes are illustrated in the mass balance, Table 5. CAPEX increases slightly to $88 \mathrm{M} €$ assuming a higher storage capacity of $8000 \mathrm{~m}^{3}$ to handle all possible species-specific capacities.

Feedstock cost is an essential driver when it comes to the profitability of the RCF-biorefinery. It is composed of different subcosts, as illustrated in Table 6 . The first cost factor is the price of the stem. Next, wood is harvested and forwarded to a collection location following by the chipping and drying processes. The last step is the transportation to the RCF-biorefinery. The total average distance is assumed to be $100 \mathrm{~km}$ for all species and $50 \mathrm{~km}$ for waste wood.

Table 7 shows how different wood species and their combinations in a dry stage (5\% moisture content) affect the profitability of the RCF-biorefinery. Note, the sugar fraction in pulp is used to calculate the pulp revenues. Birch has been already discussed in Section 3.2. NPV for birch decreases slightly due to the adapted storage capacity. For poplar, annual OPEX increases by $13.64 \%$ compared to birch. Even though the annual OPEX increases, this is compensated by higher monomers and oligomers output yields for poplar. Thus, net cash flow increases by $10 \%$ resulting in an NPV of $-18.90 \mathrm{M} €$ and IRR of $11.24 \%$. For pine, revenues remain the same and OPEX slightly increases compared to birch. This results in an NPV of M€ $€ 33$ and an IRR of $8.27 \%$. The utilization of waste wood has a positive NPV of M€ 50 and an IRR of $26 \%$. Compared to birch, feedstock cost decreased mainly by a lower drying process.

Next, different combinations of the above-mentioned species are taken into account. Depending on the region, the availability of one wood species might be insufficient to match the demands of the RCF-biorefinery and hence a variety of wood species will be required as intake. Equal proportions of birch and poplar (FC1) are considered, with an NPV of M€ -23 and an IRR of $10.43 \%$. For the combination of birch, polar, and pine (FC2), the NPV and IRR decreased further to $\mathrm{M} €-26.54$ and $9.7 \%$ due to the pine
Table 6

Feedstock cost compositions for all species.

\begin{tabular}{llllll}
\hline & & Birch & Poplar & Pine & Waste wood \\
\hline Stem $^{\mathrm{a}}$ & $€ / \mathrm{m}^{3}$ & 46.70 & 34.90 & 34.30 & $40.59^{\mathrm{e}}$ \\
Harvesting $^{\mathrm{b}}$ & $€ / \mathrm{m}^{3}$ & 10.47 & 16.28 & 9.85 & \\
Forwarding $^{\mathrm{b}}$ & $€ / \mathrm{m}^{3}$ & 9.24 & 9.24 & 9.24 & \\
Chipping $^{\mathrm{c}}$ & $€ / \mathrm{m}^{3}$ & 6.89 & 5.04 & 6.27 & 4.16 \\
Drying $^{\mathrm{d}}$ & $€ / \mathrm{m}^{3}$ & 35.58 & 30.94 & 38.48 & 7.86 \\
Transport $^{\mathrm{c}}$ & $€ / \mathrm{m}^{3}$ & 6.05 & 3.87 & 4.82 & 2.60 \\
\hline Feedstock price & $€ / \mathrm{m}^{3}$ & 114.93 & 100.27 & 102.97 & 55.21 \\
Feedstock price & $€ / \mathbf{t}$ & $\mathbf{1 7 1 . 0 3}$ & $\mathbf{2 3 2 . 9 3}$ & $\mathbf{1 9 2 . 2 8}$ & $\mathbf{9 5 . 6 1}$ \\
\hline a (Boosten et al., 2017). & & & & \\
b (Wassink, 2017). & & & & \\
c (Gybels et al., 2012). & & & \\
d Estimated from (Francescato et al., 2008). \\
e Estimated from (Garcia and Hora, 2017).
\end{tabular}

proportion. The combination of all four feedstocks (FC3) is considered as the best alternative to single-use feedstocks with an NPV of M€ -5.14 and an IRR of $14 \%$ close to the hurdle rate of $15 \%$.

3.4. Break-even point - analysis on capacity levels, feedstock costs, end-product prices, and discount rates

The midstream capacity level and the upstream feedstock supply conditions were assessed in Sections 3.1 and 3.3, respectively. Next, we analyze for which combinations of capacity level and feedstock cost, the NPV is zero. The results are presented in Fig. 5.

For a capacity level of $150 \mathrm{kt} / \mathrm{y}$ to become profitable, birch, poplar, and pine feedstock costs need to decrease to $145 € / \mathrm{t}(-15 \%)$, $214 € / \mathrm{t}(-8 \%)$, and $161 € / \mathrm{t}(-16 \%)$, respectively to reach the BEP. For waste wood, on the other hand, feedstock cost can increase to $152 € / \mathrm{t}(59 \%)$.

Under the current birch feedstock cost of $171 € / \mathrm{t}$, a capacity level of $212 \mathrm{kt} / \mathrm{y}$ is necessary to be profitable. Poplar and pine need an annual capacity level of 191 and $234 \mathrm{kt} / \mathrm{y}$, respectively, to surpass the BEP. For waste wood a capacity of $80 \mathrm{kt} / \mathrm{y}$ is sufficient. This implies that a waste wood-based RCF-biorefinery is resilient to supply shortages and can operate in locations where feedstock supply is limited. For FC1, FC2, and FC3 and their base case feedstock costs, BEP capacity levels are 202, 212, and $160 \mathrm{kt} / \mathrm{y}$,

Table 5

Mass balance changes for poplar, pine, and waste wood $(\mathrm{kg} / \mathrm{h})$

\begin{tabular}{|c|c|c|c|c|c|c|}
\hline \multirow[t]{2}{*}{ Category } & \multirow[t]{2}{*}{ Streams } & \multicolumn{2}{|c|}{$\mathrm{RCF}$} & \multicolumn{2}{|c|}{ Separation } & \multirow{2}{*}{$\begin{array}{l}\text { Balance } \\
\text { Generation }(+) \\
\text { Consumption }(-)\end{array}$} \\
\hline & & In & Out & In & Out & \\
\hline \multirow[t]{5}{*}{ Poplar ${ }^{\mathrm{a}}$} & Crude oil & & 5007.83 & 5007.83 & & 0 \\
\hline & Pulp & & 12945.76 & & & 12945.76 \\
\hline & Monomers & & & & 1833.13 & 1833.13 \\
\hline & Oligomers & & & & 1560.03 & 1560.03 \\
\hline & Wastewater & & & & 3315.55 & 3643.66 \\
\hline \multirow[t]{5}{*}{ Pine $^{\mathrm{b}}$} & Crude oil & & 4156.30 & 4156.30 & & 0 \\
\hline & Pulp & & 13797.28 & & & 13797.28 \\
\hline & Monomers & & & & 1081.24 & 1081.24 \\
\hline & Oligomers & & & & 1771.91 & 1771.91 \\
\hline & Wastewater & & & & 3021.47 & 3332.15 \\
\hline \multirow[t]{5}{*}{ Waste wood } & Crude oil & & 3668.97 & 3668.97 & & 0 \\
\hline & Pulp & & 14284.61 & & & 14284.61 \\
\hline & Monomers & & & & 865.04 & 865.04 \\
\hline & Oligomers & & & & 1719.56 & 1719.56 \\
\hline & Wastewater & & & & 2779.29 & 3113.37 \\
\hline
\end{tabular}


Table 7

Economic results for the capacity of $150 \mathrm{kt} / \mathrm{y}$ (Birch, poplar, pine, waste wood, and their combinations in dry wood condition).

\begin{tabular}{|c|c|c|c|c|c|c|c|c|}
\hline Parameters & Unit & Birch & Poplar & Pine & Waste wood & FC1 & FC2 & FC3 \\
\hline Pulp & $\mathrm{wt} \% / \mathrm{t}$ & 62.19 & 69.04 & 73.59 & 76.18 & 65.62 & 68.27 & 70.25 \\
\hline Sugar in pulp & $w t \% / t$ & 48.97 & 57.01 & 53.66 & 57.42 & 52.99 & 53.21 & 54.27 \\
\hline Monomers & $w t \% / t$ & 10.10 & 9.69 & 5.66 & 4.51 & 9.89 & 8.48 & 7.49 \\
\hline Oligomers & $\mathrm{wt} \% / \mathrm{t}$ & 6.12 & 8.31 & 9.47 & 9.17 & 7.14 & 7.97 & 8.27 \\
\hline Revenue (total) & $\mathrm{M} € / \mathrm{y}$ & 72.36 & 81.91 & 72.32 & 70.84 & 77.14 & 75.52 & 74.36 \\
\hline Pulp & $\mathrm{M} € / \mathrm{y}$ & 29.68 & 34.55 & 32.52 & 34.79 & 32.11 & 32.24 & 32.88 \\
\hline Monomers & $\mathrm{M} € / \mathrm{y}$ & 26.49 & 25.41 & 14.84 & 11.86 & 25.95 & 22.25 & 19.65 \\
\hline Oligomers & $\mathrm{M} € / \mathrm{y}$ & 16.08 & 21.84 & 24.85 & 24.08 & 18.96 & 20.92 & 21.71 \\
\hline OPEX (total) & $\mathrm{M} € / \mathrm{y}$ & 62.66 & 71.18 & 63.86 & 47.65 & 66.93 & 65.91 & 61.35 \\
\hline Feedstock cost & $\mathrm{M} € / \mathrm{y}$ & 25.65 & 34.94 & 28.84 & 14.34 & 30.30 & 29.81 & 25.94 \\
\hline NPV & $M €$ & -26.87 & -18.90 & -33.11 & 59.08 & -23.09 & -26.54 & -5.14 \\
\hline IRR & $\%$ & 9.70 & 11.24 & 8.27 & 26.08 & 10.43 & 9.70 & 14.00 \\
\hline
\end{tabular}

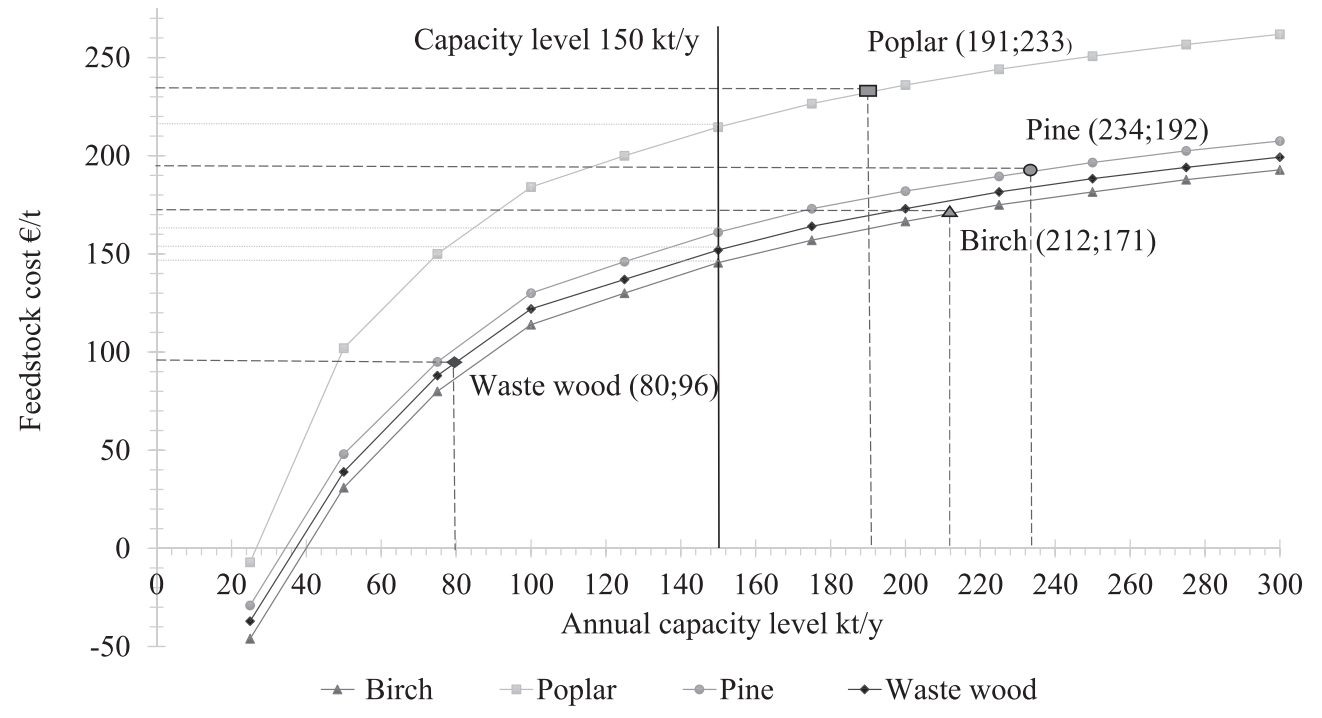

Fig. 5. Break-even point - analysis on the capacity levels and feedstock costs (the labeled markers represent the base case values for the different types of feedstock).

respectively under the current feedstock costs.

Next, downstream demand is considered to assess the endproduct price (2nd and 8th most influential variables) changes that are needed to reach the BEP, shown in Table 8. To reach the BEP, price increases between $6 \%$ and $17 \%$ are required for birch, poplar, and pine. Waste wood, on the other hand, can absorb a price decrease of around $28 \%$ for both, the pulp and lignin-based products. Regarding the feedstock combinations, price increases between $2 \%$ and $15 \%$ are sufficient to reach the BEP. To achieve higher prices it is advised to intensify R\&D efforts in RCF-technology to improve the quality of the end-products. From the demand-side perspective, competitiveness improvement of the end-products must be tackled by raising awareness of its advantages (e.g. renewable feedstock, the substitution of fossil oil-based products, etc.)

The profitability depends not only on the capacity level, feedstock cost, and the end-product price but also on how the decision-maker perceives the total risk of the project. Discount rates are chosen depending on the TRL of a project and its associated uncertainties. In our study, cost and price variables are considered to be constant which is a simplification of reality. Besides, learning effects, technological improvements, and policy uncertainties are difficult to capture and therefore hard to incorporate. To tackle these shortcomings, a risk premium is added to the risk-free discount rate to incorporate project-related uncertainties. However, some uncertainty will remain. Van Dael et al. (2015) stated that R\&D projects are usually discounted by $15 \%-$ $20 \%$. Following this advice, a discount rate of $15 \%$ was considered. However, for a very risk-averse decision-maker, a discount rate of $15 \%$ might be an optimistic value for an R\&D project with a low TRL in that early stage. For a discount rate of $20 \%$, only waste wood would be considered to be economically profitable (see IRR in

Table 8

Break-even point - analysis of end-product prices.

\begin{tabular}{|c|c|c|c|c|c|c|c|}
\hline & Birch & Poplar & Pine & Waste wood & FC1 & $\mathrm{FC} 2$ & FC3 \\
\hline Pulp price & $+15.4 \%$ & $+9.4 \%$ & $+17.3 \%$ & $-28.7 \%$ & $+12.4 \%$ & $+15.3 \%$ & $+2.7 \%$ \\
\hline Lignin-based products & $+10.7 \%$ & $+6.8 \%$ & $+14.1 \%$ & $-27.8 \%$ & $+8.7 \%$ & $+10.6 \%$ & $+2.1 \%$ \\
\hline
\end{tabular}


Table 7). When technology reaches a certain maturity stage and the products prove to be competitive and have a solid market, it is possible to assume that the discount rate might have a lower value. For instance, biomass conversion technologies in the energy sector are discounted by 10\% (Hern et al., 2015). Taking a discount rate of $10 \%$, poplar, waste wood, FC1, and FC3 prove to be competitive. Birch and FC2, on the other hand, are close to the hurdle rate of $10 \%$ with an IRR of $9.7 \%$. Pine as single-use feedstock is proved to be not competitive under the current assumptions.

\subsection{Main implications and recommendations}

\subsubsection{Valorization of wood}

Our integrated TEA assessment reveals that the RCF-technology valorizes wood on a high economic and technical level (carbon efficiency). Nevertheless, in several aspects, a significant margin for improvement still exists. For instance, Renders et al. (2018) showed significant improvement in yield outcomes by using a different solvent - a mix of $50 \%$ of n-butanol and water - under milder reaction conditions. Therefore, further research to ameliorate the RCF-process (e.g. in terms of cost reduction or revenue increase per production unit) is needed accompanied by a periodic integrated TEA assessment.

\subsubsection{Waste wood as the best alternative}

It is clearly shown that waste wood is the feedstock of choice. Lab stage-based results indicate that waste wood (type B) is technically suitable for the RCF-process. However, it is often neglected as a feedstock for high-value end-products due to the presence of contamination (Kutnar and Muthu, 2016). Further in-depth research is required to identify these contaminants (organic and inorganic) and quantitatively allocate their mass flow throughout the biorefinery and into the different product streams. From a cascading point of view, waste wood under the RCF-biorefinery creates more added value than in other sectors (e.g. energy). However, the waste wood market is almost fully saturated. Besides, new EU targets for 2030 to reduce greenhouse emission by using biomass, including waste wood, are limiting the utilization of waste wood (European Commission, 2017). Thus, RCF-biorefinery would face stronger competition. On the other hand, the profit margin could be sufficient to absorb price shocks up to a price level of 152 $€ / t$ for a capacity level of $150 \mathrm{kt} / \mathrm{y}$ (Fig. 5). Another point of attention is market acceptance. From the consumer perspective, waste wood-based end-products might face difficulties to be accepted due to the contamination issue. From the legal point of view, sensitive sectors (e.g. agriculture) have strict regulations. Therefore, policies are needed to lift barriers to use waste wood as a feedstock and increase market acceptance. Undoubtedly, such policies must be supported by studies, confirming limited environmental impact and toxicity for end-users, and if required specific waste wood quality standards must be implemented. Consequently, it would assure the safety of the end-products sending a positive signal to the consumers.

\subsubsection{Value chain-specific integration}

Depending on the capacity level and the associated wood supply, a market entry might disturb the market. Three scenarios are possible: (a) The feedstock supply-side absorbs the additional demand with no-to-small impact on future wood prices. (b) The market might be saturated and additional wood demand would cause scarcity and increasing feedstock costs leading to a nonprofitable project. And even if the RCF-biorefinery can pay higher feedstock prices, certain species could not be available due to supply shortage (e.g. new regulations, policy changes, pesticide infection, geographical location, etc.). Näyhä (2019) stated that, for certain high-quality products, it is a challenge to find a specific type of wood. Building on that, the use of waste wood could minimize such species-specific supply constraints. Section 3.3 showed that a feedstock mix including waste wood brings significant economic improvement and that single-use waste wood is already profitable at a capacity level of $80 \mathrm{kt} / \mathrm{y}$. (c) Additional wood demand could also act as a feedstock price stabilization mechanism. This mechanism is likely to become even more important in future climatic conditions were forest disturbances (storms, pathogens, insects, and drought), which can have the effect of temporal high feedstock oversupply and price drops, are expected to increase in activity (Seidl et al., 2017). Due to the feedstock flexibility of the RCF-biorefinery process, price shocks could be absorbed by switching to a different type of feedstock.

Another point associated with feedstock availability is the optimal location of the RCF-biorefinery. The location must be strategically chosen considering easy access to feedstock supply and wood value chain infrastructure. It needs to be assessed whether the infrastructure already exists, if additional extensions are needed, or if a new RCF-biorefinery-tailored infrastructure must be established. The optimal location also depends on other factors. The envisioned RCF-biorefinery does not incinerate $\mathrm{H}_{2}$ gas bypass waste streams itself and therefore would allocate these streams to an external incinerator, thus limiting the location choice. Hydrogen prices are determined by accessibility and transportation cost. We used a price of $2100 € / t$ assuming access on a large industrial scale with no-to-short transportation distance. Lowering the accessibility to a small industrial scale with longer transportation distance could lead to a price increase of up to $6000 € / \mathrm{t}$ (Thomas et al., 2016).

Hence, based on our assessment it is recommended to design the RCF-biorefinery and its infrastructure in a flexible way to tackle the above-mentioned supply-side based uncertainties. Because of RCF-technology flexibility, decision-makers should also consider different feedstocks or feedstock combinations to overcome supply-side challenges. Several constraints limit the location choice. Due to the hydrogen accessibility and $\mathrm{H}_{2}$ gas bypass waste stream incineration, chemical- or Bio-hubs with access to hydrogen seems to be suitable for the RCF-biorefinery.

\subsubsection{Use of wet wood due to reduced processing costs}

Following up on the sensitivity analysis (Section 3.2), the use of wet feedstock, which requires less processing compared to dry wood, can decrease the cost and the environmental burden of the feedstock. One of the main cost drivers of feedstock is drying. It amounts between $31 \%$ and $37 \%$ of the total cost of virgin wood (Table 6). Reducing the drying cost would also lead to a decrease in greenhouse emissions. Schutyser et al. (2015) showed that wet wood is applicable for the RCF-process. However, due to the absorbed water in wet wood transportation cost increases. Therefore, further research is needed to conclusively show the advantage of wet wood as an alternative to dry wood.

\section{Conclusion}

An integrated TEA was developed to solve the rigidness of traditional TEAs by mutual multi-linkage between input and intermediate variables, which eventually results in multiple chosen output variables. Besides, this integrated TEA introduces new parameters (e.g. moisture content) that are giving the decision-maker new insights and in-depth assessment possibilities between the technical and economic processes on a low TRL-based technology using laboratory studies. Furthermore, the TEA is designed as a modular system allowing to combine it with different disciplinary models. All of these features are making integrated TEA's indispensable for R\&D projects. An economic feasibility study on the 
reductive catalytic fractionation-process was performed which targets the conversion of wood into higher-value end-products. A detailed process flow diagram and mass and energy balance for a capacity level of $150 \mathrm{kt} / \mathrm{y}$ wood feedstock input were displayed. First, different capacity levels (20, 75, $150 \mathrm{kt} / \mathrm{y})$ were assessed showing that scale has a large impact on profitability advising to focus on optimizing the plant facilities and its operations. Second, a Monte-Carlo sensitivity analysis was carried out assessing the most influential parameters. Third, the economic feasibility of different feedstock species and its combinations were assessed revealing species-specific impacts on the different processing stages and associated product yields and illustrating the importance of species-specific cost and price structure. Our assessment revealed that waste wood is the feedstock of choice. The break-even pointanalyzes show the potential of waste wood to absorb several economic shocks such as; end-product price decrease $(-28 \%)$ on the demand-side, feedstock cost increases (59\%), and a feedstock availability decrease to $80 \mathrm{kt} / \mathrm{y}$ on the supply-side. Nevertheless, the results should be interpreted with caution due to potential wood value chain-specific constraints, such as supply availability, optimal location choice.

Conclusively, our integrated TEA shows to be an indispensable tool to not only assess the economic feasibility of a biorefinery but also to define a multi-dimensional strategy of choosing the appropriate scale with possible optimal feedstock combinations under the most promising wood value chain conditions.

\section{Declaration of competing interest}

The authors declare that they have no known competing financial interests or personal relationships that could have appeared to influence the work reported in this paper.

\section{CRediT authorship contribution statement}

Maxim Tschulkow: Conceptualization, Methodology, Software, Validation, Formal analysis, Investigation, Resources, Data curation, Writing - original draft, Writing - review \& editing, Visualization. Tine Compernolle: Conceptualization, Writing - review \& editing, Supervision. Sander Van den Bosch: Resources, Writing - review \& editing. Joost Van Aelst: Resources, Writing - review \& editing. Ilié Storms: Resources, Writing - review \& editing. Miet Van Dael: Writing - review \& editing. Gil Van den Bossche: Resources. Bert Sels: Resources, Writing - review \& editing. Steven Van Passel: Conceptualization, Writing - review \& editing, Supervision.

\section{Acknowledgments}

This project has received funding from the Research Foundation Flanders (FWO)-SBO BIOWOOD project. Tine Compernolle thanks the (FWO) for funding her postdoctoral mandate with Grant number 12M7417N. G. V.d.B. acknowledges funding from FISCHICON project MAIA. J.V.A. and S.V.d.B acknowledge Flanders Innovation \& Entrepreneurship (VLAIO) for their innovation mandate.

\section{Nomenclature}

$\begin{array}{ll}\text { Abbreviations } \\ \text { CAPEX } & \text { Capital expenditure } \\ € & \text { Euro } \\ \text { FC } & \text { Feedstock combination } \\ \text { IRR } & \text { Internal rate of return } \\ \text { MEB } & \text { Mass and energy balance } \\ \text { M€ } & \text { Million euro }\end{array}$

$\begin{array}{ll}\text { NPV } & \text { Net present value } \\ \text { OPEX } & \text { Operational expenditure } \\ \text { PFD } & \text { Process flow diagram } \\ \text { R\&D } & \text { Research and development } \\ \text { RCF } & \text { Reductive catalytic fractionation } \\ \text { TEA } & \text { Techno-economic assessment } \\ \text { TRL } & \text { Technology readiness level }\end{array}$

$\begin{array}{ll}\text { Subscripts } \\ \mathrm{BEP} & \text { Break-even point } \\ \mathrm{CF}_{\mathrm{t}} & \text { Net cash flows generated in year t } \\ \mathrm{h} & \text { Hour } \\ \mathrm{H}_{2} & \text { Hydrogen } \\ \mathrm{i} & \text { Discount rate } \\ \mathrm{I}_{0} & \text { Initial investment (CAPEX) in year 0 } \\ \mathrm{kWh}^{3} & \text { Kilowatt-hour } \\ \mathrm{m}^{3} & \text { Cubic meter } \\ \mathrm{kg} & \text { Kilogram } \\ \mathrm{kt} & \text { Metric kiloton } \\ \mathrm{t} & \text { Metric ton } \\ \mathrm{n} & \text { Project lifetime } \\ \mathrm{Ru} / \mathrm{C} & \text { Ruthenium on carbon } \\ \mathrm{y} & \text { Year } \\ \mathrm{wt} \% & \text { Weight percent }\end{array}$

\section{References}

Bond, J.Q., Upadhye, A.A., Olcay, H., Tompsett, G.A., Jae, J., Xing, R., Alonso, D.M., Wang, D., Zhang, T., Kumar, R., Foster, A., Sen, S.M., Maravelias, C.T., Malina, R., Barrett, S.R.H., Lobo, R., Wyman, C.E., Dumesic, J.A., Huber, G.W., 2014. Production of renewable jet fuel range alkanes and commodity chemicals from integrated catalytic processing of biomass. Energy Environ. Sci. 7, 1500-1523. https://doi.org/10.1039/C3EE43846E.

Boosten, M., Voncken, F., Van der Heyden, D., Oldenburger, J., De Somviel, B., 2017 eco2eco werkpakket 3 - Vraag en aanbod op de houtmarkt in Nederland en Vlaanderen. activiteit II - Analyse rondhoutprijzen en prijsbepalende parameters. https://www.probos.nl/rapporten-2017/1416-vraag-en-aanbod-op-dehoutmarkt-in-nederland-en-vlaanderen-toekomstige-vraag-naar-kwaliteitshout-in-relatie-tot-het-mogelijke-aanbod. (Accessed 18 December 2019).

Bridgwater, A.V., Toft, A.J., Brammer, J.G., 2002. A techno-economic comparison of power production by biomass fast pyrolysis with gasification and combustion Renew. Sustain. Energy Rev. 6, 181-246. https://doi.org/10.1016/S13640321(01)00010-7.

Budzinski, M., Nitzsche, R., 2016. Comparative economic and environmental assessment of four beech wood based biorefinery concepts. Bioresour. Technol. 216, 613-621. https://doi.org/10.1016/j.biortech.2016.05.111.

Calvo-Flores, F.G., Dobado, J.A., 2010. Lignin as renewable raw material. ChemSusChem 3, 1227-1235. https://doi.org/10.1002/cssc.201000157.

Cheali, P., Posada, J.A., Gernaey, K.v., Sin, G., 2016. Economic risk analysis and critical comparison of optimal biorefinery concepts. Biofuels Bioprod. Bioref. 10, 435-445. https://doi.org/10.1002/bbb.1654.

Cooper, R.G., 1990. Stage-gate systems: a new tool for managing new products. Bus. Horiz. 33, 44-54. https://doi.org/10.1016/0007-6813(90)90040-I.

European Commission, 2017. Sustainable and Optimal Use of Biomass for Energy in the EU beyond 2020. https://ec.europa.eu/energy/en/studies/sustainable-andoptimal-use-biomass-energy-eu-beyond-2020. (Accessed 6 March 2020).

European Commission, 2019. Sugar Price Reporting. AGRI G 4-Committee for the Common Organisation of Agricultural Markets. https://ec.europa.eu/ agriculture/market-observatory/sugar/statistics_de. (Accessed 11 February 2019).

Francescato, V., Antonini, E., Bergomi, L.Z., Metschina, C., Schnedl, C., Krajnc, N., Koscik, K., Gradziuk, P., Nocentini, G., Stranieri, S., 2008. Wood Fuels Handbook Italy.

Garcia, C.A., Hora, G., 2017. State-of-the-art of waste wood supply chain in Germany and selected European countries. Waste Manag. 70, 189-197. https://doi.org/ 10.1016/j.wasman.2017.09.025.

Gybels, R., Wouters, R., Schuurmans, B., Verbeke, W., 2012. Houtige Biomassa Voor Energie in Limburg. Eindrapport Van Het MIP2-Project "Limburgs Groen Voor Een Groene Economie", p. 159. https://www.ecopedia.be/zoeken/Houtige\% 20biomassa\%20voor\%20energie\%20in\%20Limburg. (Accessed 6 March 2020).

Hern, R., Radov, D., Carmel, A., Spasovska, M., Guo, J., 2015. Electricity generation costs and hurdle rates. Lot 1: hurdle rates update for generation technologies. https://www.gov.uk/government/publications/nera-2015-hurdle-rates-updatefor-generation-technologies. (Accessed 14 December 2019).

Kamm, B., Gruber, P.R., Kamm, M., 2010. In: Kamm, Birgit, Gruber, Patrick R., Kamm, Michael (Eds.), Biorefineries - Industrial Processes and Products. Status 
Quo and Future Directions. Wiley-VCH, Weinheim.

Kühmaier, M., Erber, G., Kanzian, C., Holzleitner, F., Stampfer, K., 2016. Comparison of costs of different terminal layouts for fuel wood storage. Renew. Energy 87, 544-551. https://doi.org/10.1016/j.renene.2015.10.048.

Kuppens, T., Van Dael, M., Vanreppelen, K., Thewys, T., Yperman, J., Carleer, R. Schreurs, S., Van Passel, S., 2015. Techno-economic assessment of fast pyrolysis for the valorization of short rotation coppice cultivated for phytoextraction. J. Clean. Prod. 88, 336-344. https://doi.org/10.1016/j.jclepro.2014.07.023.

Kutnar, A., Muthu, S.S., 2016. Environmental Impacts of Traditional and Innovative Forest-Based Bioproducts. Springer, Singapore.

Liao, Y., Koelewijn, S.-F., Van den Bossche, G., Van Aelst, J., Van den Bosch, S. Renders, T., Navare, K., Nicolaï, T., Van Aelst, K., Maesen, M., Matsushima, H. Thevelein, J., Van Acker, K., Lagrain, B., Verboekend, D., Sels, B.F., 2020. A sustainable wood biorefinery for low-carbon footprint chemicals production. Science (New York, N.Y.) 367, 1385-1390. https://doi.org/10.1126/ science.aau1567.

Messier, C., Bauhus, J., Doyon, F., Maure, F., Sousa-Silva, R., Nolet, P., Mina, M. Aquilué, N., Fortin, M.-J., Puettmann, K., 2019. The functional complex network approach to foster forest resilience to global changes. For. Ecosyst. 6, 617. https://doi.org/10.1186/s40663-019-0166-2.

Michel, A., Seidling, W., Prescher, A.-K., 2018. Forest Condition in Europe: 2018 Technical Report of ICP Forests. Report under the UNECE Convention on LongRange Transboundary Air Pollution (Air Convention). BFW Austrian Research Centre for Forests, Vienna, p. 92.

Näyhä, A., 2019. Transition in the Finnish forest-based sector: company perspectives on the bioeconomy, circular economy and sustainability. J. Clean. Prod 209, 1294-1306. https://doi.org/10.1016/j.jclepro.2018.10.260.

Peters, M.S., Timmerhaus, K.D., West, R.E., 2003. Plant Design and Economics for Chemical Engineers, 5th Ed.. McGraw-Hill, Boston, London.

Renders, $T$, Cooreman, E, Van den Bosch, S, Schutyser, W, Koelewijn, S.-F Vangeel, T., Deneyer, A., Van den Bossche, G., Courtin, C.M., Sels, B.F., 2018. Catalytic lignocellulose biorefining in $\mathrm{n}$-butanol/water: a one-pot approach toward phenolics, polyols, and cellulose. Green Chem. 311, 484. https://doi.org/ 10.1039/C8GC01031E.

Renders, T., Schutyser, W., Van den Bosch, S., Koelewijn, S.-F., Vangeel, T., Courtin, C.M., Sels, B.F., 2016. Influence of acidic (H 3 PO 4 ) and alkaline (NaOH) additives on the catalytic reductive fractionation of lignocellulose. ACS Catal. 6 2055-2066. https://doi.org/10.1021/acscatal.5b02906.

Renders, T., Van den Bosch, S., Koelewijn, S.-F., Schutyser, W., Sels, B.F., 2017. Ligninfirst biomass fractionation: the advent of active stabilisation strategies. Energy Environ. Sci. 10, 1551-1557. https://doi.org/10.1039/C7EE01298E.

Renders, T., Van den Bossche, G., Vangeel, T., Van Aelst, K., Sels, B., 2019. Reductive catalytic fractionation: state of the art of the lignin-first biorefinery. Curr. Opin. Biotechnol. 56, 193-201. https://doi.org/10.1016/j.copbio.2018.12.005.

Rockström, J., Steffen, W., Noone, K., Persson, A., Chapin, F.S., Lambin, E.F.,
Lenton, T.M., Scheffer, M., Folke, C., Schellnhuber, H.J., Nykvist, B., de Wit, C.A., Hughes, T., van der Leeuw, S., Rodhe, H., Sörlin, S., Snyder, P.K., Costanza, R., Svedin, U., Falkenmark, M., Karlberg, L., Corell, R.W., Fabry, V.J., Hansen, J., Walker, B., Liverman, D., Richardson, K., Crutzen, P., Foley, J.A., 2009. A safe operating space for humanity. Nature 461, 472-475. https://doi.org/10.1038/ 461472a.

Schutyser, W., Renders, T., Van den Bosch, S., Koelewijn, S.-F., Beckham, G.T., Sels, B.F., 2018. Chemicals from lignin: an interplay of lignocellulose fractionation, depolymerisation, and upgrading. Chem. Soc. Rev. 47, 852-908. https:// doi.org/10.1039/c7cs00566k.

Schutyser, W., Van den Bosch, S., Renders, T., de Boe, T., Koelewijn, S.-F., Dewaele, A., Ennaert, T., Verkinderen, O., Goderis, B., Courtin, C.M., Sels, B.F., 2015. Influence of bio-based solvents on the catalytic reductive fractionation of birch wood. Green Chem. 17, 5035-5045. https://doi.org/10.1039/C5GC01442E.

Seidl, R., Thom, D., Kautz, M., Martin-Benito, D., Peltoniemi, M., Vacchiano, G., Wild, J., Ascoli, D., Petr, M., Honkaniemi, J., Lexer, M.J., Trotsiuk, V., Mairota, P., Svoboda, M., Fabrika, M., Nagel, T.A., Reyer, C.P.O., 2017. Forest disturbances under climate change. Nat. Clim. Change 7, 395-402. https://doi.org/10.1038/ nclimate3303.

Sinnott, R.K., Towler, G.P., 2019. Chemical Engineering Design, sixth ed. Butterworth-Heinemann, Amsterdam. Ray Sinnott, Gavin Towler.

Thomas, D., Mertens, D., Meeus, M., Van der Laak, W., Francois, I., 2016. Power-toGas Roadmap for Flanders. https://www.power-to-gas.be/. (Accessed 16 December 2019).

Thomassen, G., Van Dael, M., Van Passel, S., You, F., 2019. How to assess the potential of emerging green technologies? Towards a prospective environmental and techno-economic assessment framework. Green Chem. 21, 4868-4886. https:/ doi.org/10.1039/C9GC02223F.

Van Dael, M., Kuppens, T., Lizin, S., Van Passel, S., 2015. Techno-economic assessment methodology for ultrasonic production of biofuels. In: Smith, R.L., Qi, X. (Eds.), Production of Biofuels and Chemicals with Ultrasound. Springer, Dordrecht, pp. 317-345.

Van den Bosch, S., Schutyser, W., Vanholme, R., Driessen, T., Koelewijn, S.-F., Renders, T., de Meester, B., Huijgen, W.J.J., Dehaen, W., Courtin, C.M., Lagrain, B., Boerjan, W., Sels, B.F., 2015. Reductive lignocellulose fractionation into soluble lignin-derived phenolic monomers and dimers and processable carbohydrate pulps. Energy Environ. Sci. 8, 1748-1763. https://doi.org/10.1039/C5EE00204D.

Verkerk, P.J., Fitzgerald, J.B., Datta, P., Dees, M., Hengeveld, G.M., Lindner, M., Zudin, S., 2019. Spatial distribution of the potential forest biomass availability in Europe. For. Ecosyst. 6, 124. https://doi.org/10.1186/s40663-019-0163-5.

Wassink, W., 2017. Handvat Voor Financieel Duurzaam Bosbeheer. https://hbokennisbank.nl/details/samhao:oai:www.samhao.nl:VBS:2:142931? $\mathrm{q}=$ HANDVAT + VOOR +FINANCIEEL+DUURZAAM +BOSBEHEER\&amp; haslink=yes. (Accessed 18 December 2019). 